\title{
Robbe De Hert: beeldenstormer, publieksfilmer en promotor van de filmgeschiedenis
}

\begin{abstract}
Het oeuvre van de Belgische cineast Robbe De Hert (20 september 1942 - 24 augustus 2020) is erg divers. Hij realiseerde experimentele animatiefilms (A Funny Thing Happened on my Way to Golgotha) en maatschappijkritische filmpamfletten (Camera sutra), maar evengoed een populaire komedie (Zware jongens), een adaptatie van een historische plattelandsroman (De Witte van Sichem) of een Willem Elsschotverfilming (Lijmen/Het been). De Hert was het boegbeeld van het in 1966 opgerichte filmerscollectief Fugitive Cinema, dat de Belgische cinema een sociale dimensie gaf. Hij gold jarenlang als de grootste criticaster van het Vlaamse film- en televisiebeleid. Vanaf de jaren 1980 ontpopte De Hert zich met zijn documentaires ook als hoeder en promotor van de (vooral Belgische maar ook Nederlandse) filmgeschiedenis. Dit artikel belicht zowel De Herts bijdrage aan als zijn engagement voor de filmgeschiedenis. Afsluitend gaat het artikel in op De Herts omvangrijke Fugitive Cinema Archief.
\end{abstract}

\section{Trefwoorden}

Robbe De Hert; Fugitive Cinema; Belgische film; Nederlandse film; sociale film

De zomer van 2020 was niet mals voor Belgische cineasten van een zekere leeftijd. In juni wisselde Marion Hänsel (71) het tijdelijke voor het eeuwige, in juli Lydia Chagoll (89), en op 24 augustus Robbe De Hert (77). Drie filmmakers met een volstrekt eigen stem. Bij De Hert was die stem doorspekt met een temperamentvol Antwerps accent, sociaal engagement en een grenzeloze liefde voor alles wat van ver of dicht met film te maken had.

De Herts oeuvre is ontzettend veelzijdig. Van experimentele animatiefilms tot maatschappijkritische filmpamfletten, van metafilm tot populaire komedie, van semi-autobiografische 
drama's tot een oorlogsfilm over het verzet, en van de adaptatie van een historische plattelandsroman tot een Willem Elsschotverfilming: De Hert deed het allemaal. Hij was het boegbeeld van het in 1966 opgerichte filmerscollectief Fugitive Cinema, dat de Belgische cinema een sociale dimensie gaf. Hij gold ook jarenlang als de grootste criticaster van het Vlaamse film- en televisiebeleid. Maar De Herts belang voor de filmgeschiedenis reikt verder dan zijn eigen rol erin. Vanaf de jaren 1980 realiseerde hij een reeks documentaires over film. Zo ontpopte hij zich als hoeder en promotor van de (vooral Belgische maar ook Nederlandse) filmgeschiedenis. Dit artikel belicht zowel De Herts bijdrage aan als zijn engagement voor de filmgeschiedenis. Afsluitend gaat het in op de plannen met De Herts omvangrijke Fugitive Cinema Archief.

\section{Cinemaloper}

Robin 'Robbe’ De Hert werd op 20 september 1942 geboren in het Engelse Farnborough. Na de oorlog vestigde zijn gezin zich in de buurt van Antwerpen, de stad waarmee De Hert de rest van zijn leven nauw verbonden zou zijn. Antwerpen kende in die naoorlogse jaren een enorme bloei aan bioscopen en het filmbezoek scheerde ongekend hoge toppen. ${ }^{1}$ Een van die bezoekers was De Hert: al van jongs af aan was hij een echte 'cinemaloper', zoals hij het zelf noemde.

De jonge De Hert verslond alles wat hij te zien kon krijgen, zonder onderscheid. Als de beelden maar bewogen, was hij erdoor gefascineerd. Met de jaren werd hij selectiever in zijn appreciatie, maar een filmveelvraat zou hij altijd blijven. Ook toen zijn gezondheid het nog nauwelijks toeliet, ging hij vaak meerdere malen per dag naar de bioscoop voor een ratjetoe aan films. De Herts veelzijdige filmconsumptie zou zich later ook vertalen in zijn eigen filmproductie.

$\mathrm{Na}$ een opleiding als elektricien en diverse jobs waaronder manusje-van-alles binnen het Antwerpse bioscoopimperium van Georges Heylen, begon hij als jonge twintiger zelf met een camera te experimenteren. Met als enige filmschool de bioscoop stelde De Hert in 1964 op het Festival van de Belgische Film te Antwerpen twee korte fictiefilms voor. Twee keer 2 ogen en An Old Story werden er meteen bekroond, respectievelijk met de Prijs voor het Beste Debuut en de Prijs van de Kritiek. ${ }^{2}$ Jury en pers waren laaiend enthousiast. Vooral schrijfster en De Standaard-journaliste Maria Rosseels, de 


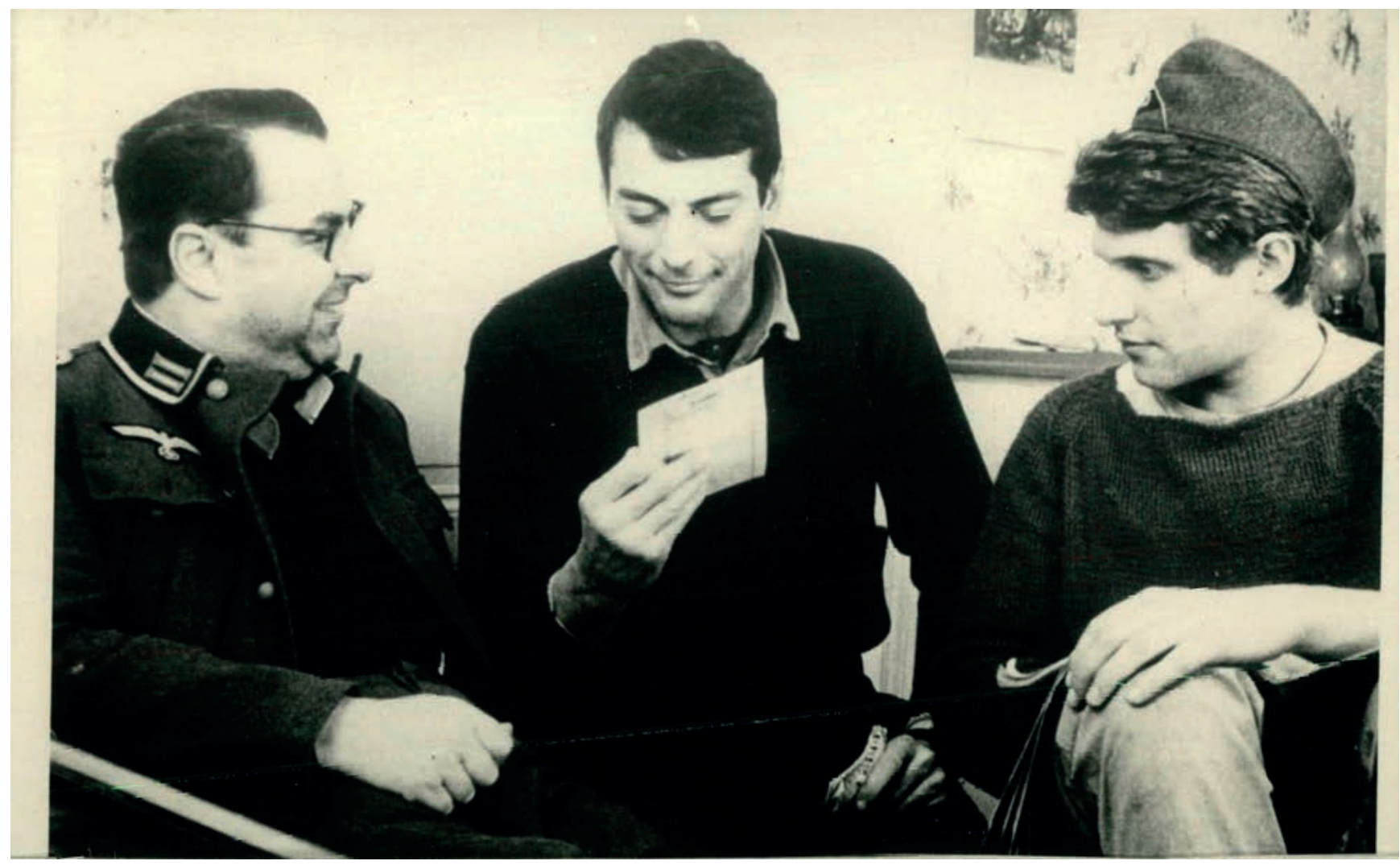

Afbeelding 1: Still uit Hugo Claus'speelfilmdebuut De Vijanden (1967), waarin (v.l.n.r.) Fons Rademakers, Del Negro en Robbe De Hert de hoofdrollen vertolken. Bron: DOCIP.

toenmalige gezaghebbende filmcritica in Vlaanderen, was vol lof over het visuele talent van dit 'wonderkind': 'Robbe is een van die begenadigde mensen die werkelijk niet alleen visueel zien, zoals het woord het zelf zegt, maar die visueel denken. ${ }^{3}$

Op zoek naar filmervaring trok De Hert vervolgens korte tijd naar Londen, waar hij in contact kwam met de Britse Free Cinema beweging. Cineasten als Lindsay Anderson, Karel Reisz en Tony Richardson inspireerden hem met hun alternatieve films. Terug in Antwerpen kon hij proeven van zijn jongensdroom om filmster te worden. Zo speelde hij naast de Nederlandse acteur en regisseur Fons Rademakers en de Amerikaanse acteur Del Negro in Hugo Claus’ regiedebuut De vijanden (1967) en vertolkte hij een rol in Rik Kuijpers' nooit afgewerkte film Adieu Filippi (1968). Later zou De Hert gastrollen in diverse films blijven aannemen, van opstandeling in Rubens, schilder en diplomaat (1977, 
Roland Verhavert) tot barman in Flodder (1986, Dick Maas), maar intussen had hij zijn zinnen volledig gezet op het realiseren van films.

\section{Fugitive Cinema}

$\mathrm{Na}$ eerder al actief te zijn geweest in de ambitieuze amateurfilmclub Filmgroep'58 (met onder andere ook Harry Kümel in de rangen), stond De Hert aan de wieg van het op 17 maart 1966 opgerichte filmerscollectief Fugitive Cinema. Medeoprichters waren zijn broer Jos (de cartoonist 'Grapjos') en zijn vrienden Walter Heynen (componist), Kris Van den Bogaert (uitgever), de broers Toon en Louis Celis en hun vader Frans Celis (fotografen). De avant-gardistische dichter Paul De Vree fungeerde als voorzitter en als lijm tussen de verenigde filmmakers. Iets later sloten ook Guido Henderickx en Patrick Le Bon zich aan, wat een sterke dynamiek aan het collectief gaf. Waar er in Nederland in de jaren 1960 en 1970 wel meer aan film gerelateerde collectieven het licht zagen, vormt Fugitive Cinema veeleer een uitzondering in de Belgische filmgeschiedenis.

Fugitive Cinema had een distributieafdeling waarmee het de eigen producties maar vooral ook internationale alternatieve films verdeelde in België. In 1971 richtte Willem Thijssen, toen nog student aan de Nederlandse Filmacademie en later frequent producent en co-realisator voor De Herts films, de distributiemaatschappij Fugitive Cinema Holland op, samen met studiegenoot Jan Röfekamp. Deze distributieactiviteiten pasten binnen een ruimere beweging die ijverde voor een betere verdeling van artistiek waardevolle en/of politiek geëngageerde films. Zo ontstond in Nederland in 1972 ook het Rotterdams filmfestival met een eigen distributiepoot, Film International, en in 1974 het feministisch filmcollectief Cinemien. Toen in 1984 de ministeriële subsidies voor Fugitive Cinema Holland onverwacht werden stopgezet, kwam het tot een fusie met het Nederlands Film Instituut. De Belgische distributieafdeling van Fugitive Cinema werkte intussen samen met Cinélibre, waar het in 1988 in zou opgaan.

Samen met een aantal andere progressieve culturele en politieke groeperingen was Fugitive Cinema in de jaren 1970 gehuisvest vlakbij het Antwerpse film-, muziek-, debat- en cultuurhuis de King Kong (eigenlijk 'Kultureel Informatief Centrum Keizerstraat' of KICK), dat De Hert in 1972 mee had opgericht. Op die manier kende Fugitive Cinema een zekere graad van verticale integratie, want naast de productie- en distributieactiviteiten was Fugitive ook nauw betrokken bij de filmvertoningen in de King Kong. 


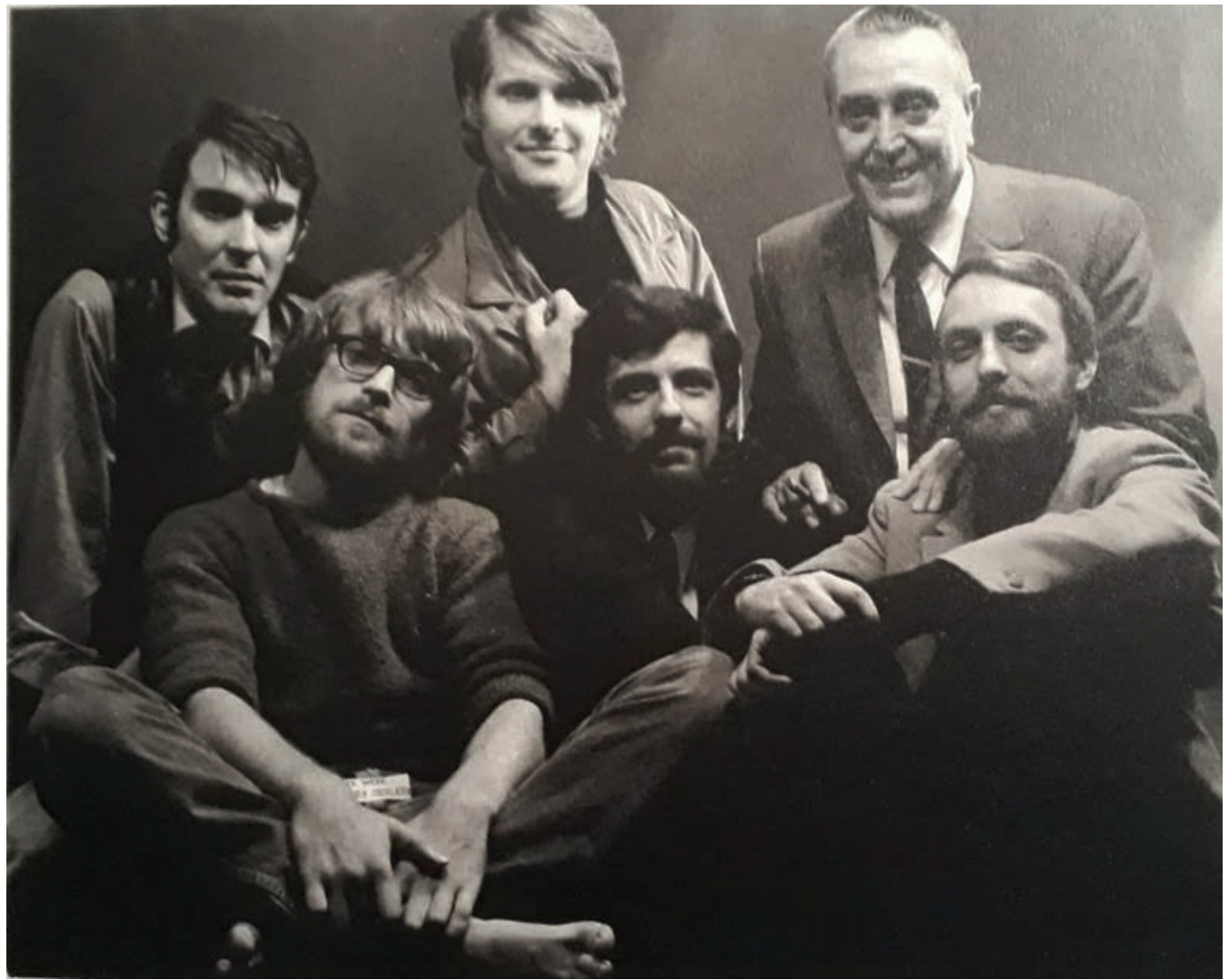

Afbeelding 2: Enkele Fugitive Cinema-leden in 1970. V.l.n.r. (boven) Patrick Le Bon, Robbe De Hert, Paul De Vree, (onder) Jos De Hert, Louis Celis, Guido Henderickx. Bron: Fugitive Cinema Archief (foto: Studio Celis).

\section{Enfant terrible}

Voor hun filmproducties verwees het collectief ook wel naar zichzelf als 'Paul De Vree and his lonely filmers', omdat ze in de marge werkten, buiten en meestal ook tegen 'het systeem', de maatschappelijke status quo met zijn officiële instanties waartegen de filmmakers fulmineerden. Een geperforeerde piratenvlag gold als het symbool van Fugitive Cinema.

Het romantische vrijbuitersbeeld dat Fugitive zelf cultiveerde verdient evenwel enige nuancering. Zo was De Vree tot 1978 zelf lid van de filmcommissie, die de minister van Cultuur adviseerde over de subsidieverdeling (en maakte Fugitive dus ook deel uit van het establishment dat het bestreed), en gaf diezelfde filmcommissie dikwijls net blijk van 
waardering voor het filmerscollectief. Joz. Van Liempt, die van 1964 tot 1978 voorzitter van de filmcommissie was, verwoordde het in een terugblik ter ere van 25 jaar Fugitive Cinema als volgt: 'Robbe De Hert en al die jongeren die in de loop der jaren bij Fugitive Cinema kwamen en gingen, hebben zich tegenover de filmcommissie of om het even welke overheidsinstantie altijd uitgesproken non-conformistisch gedragen, en toch hebben zij altijd op sympathie kunnen rekenen.' ${ }^{4}$

Met de jaren verzuurde De Herts relatie met het filmbeleid echter, en in de laatste twintig jaar van zijn carrière werden bijna al zijn steunaanvragen afgewezen. Opeenvolgende filmcommissies, ministers en later het Vlaams Audiovisueel Fonds (VAF) verweet hij incompetentie en actieve tegenwerking. Omgekeerd had het filmbeleid moeite met De Herts nalatigheid in verband met bepaalde gesteunde projecten die maar niet afgewerkt raakten, zijn vaak slordige en onvolledige steunaanvragen, en de penibele financiële solvabiliteit van Fugitive Cinema. ${ }^{5}$

Ook het voortdurende gevecht met de openbare omroep en allerlei andere instanties vormt een rode draad doorheen De Herts carrière. Zijn rebelse, weinig diplomatieke temperament leverde hem al vroeg het label 'enfant terrible van de Vlaamse cinema' op. De Hert kon zijn ongezouten mening over het film- en televisiebeleid en allerlei andere filmgerelateerde zaken kwijt in de kolommen van het in 1978 opgerichte filmtijdschrift Andere Sinema (dat eveneens kantoor hield boven de King Kong), in diverse andere media en in de ontelbare interviews die hij zijn leven lang gaf. Hij was een vaak gevraagde gast voor debatten en gold als gangmaker van vele protestacties. 


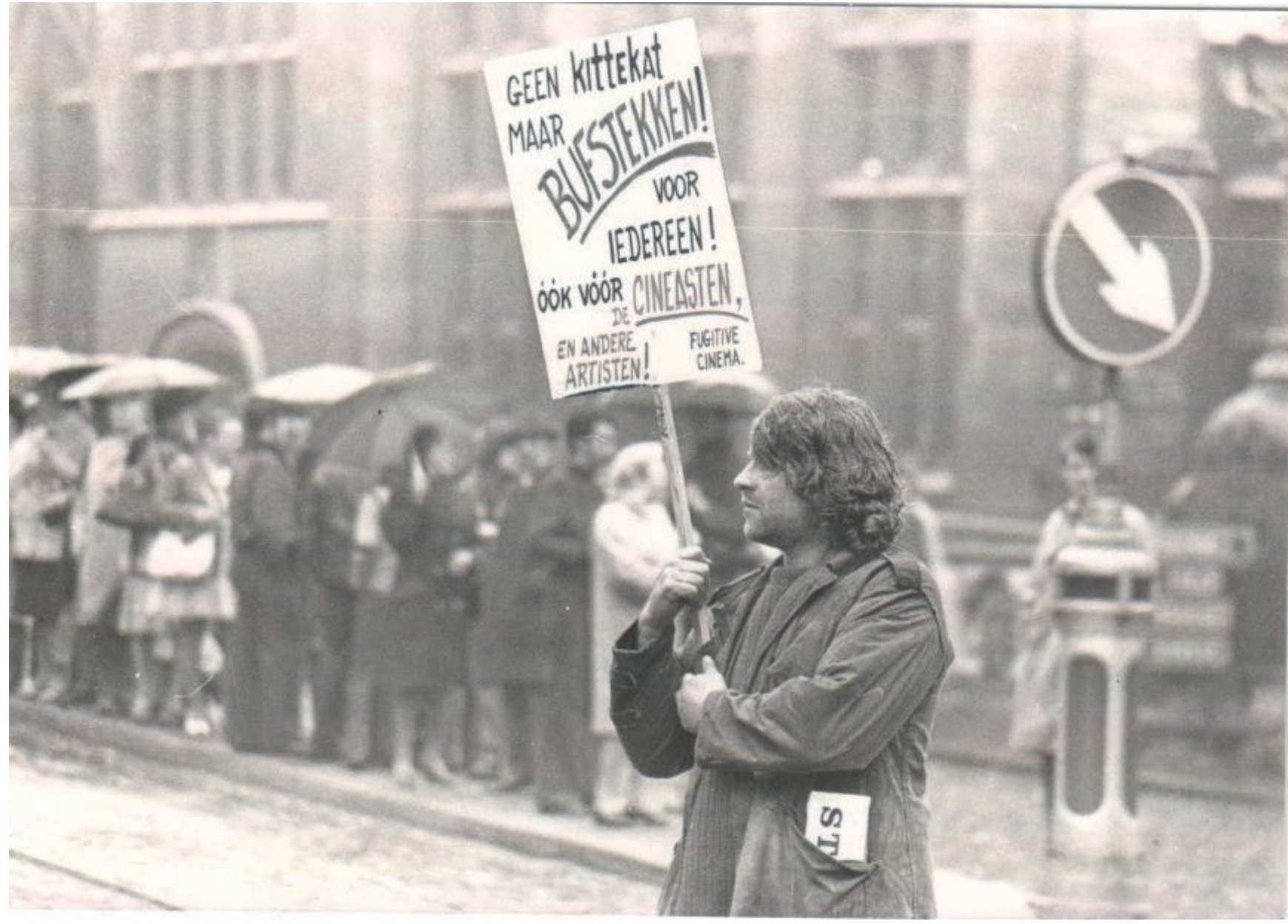

Afbeelding 3: Robbe De Hert tijdens een protestactie tegen het filmbeleid in 1974: 'Geen kittekat maar bufstekken! Voor iedereen! Óók vóór de cineasten en andere artiesten!’ Bron: Fugitive Cinema Archief.

\section{Beeldenstormers}

Samen met bevriend cineast Frans Buyens injecteerde Fugitive Cinema de Belgische film met een dosis politiek en maatschappelijk engagement. Dat zorgde voor een frisse wind in een productielandschap dat in die jaren gedomineerd werd door twee stromingen, door Ernest Mathijs benoemd als enerzijds 'commercial/exploitation cinema' en anderzijds 'auteurist/culturally relevant cinema'. ${ }^{6}$ In beide strekkingen, die verder weinig met elkaar gemeen hadden, was de sociale betrokkenheid meestal ver te zoeken. In die leemte eiste het Fugitive-collectief luidruchtig zijn plaats op. 
Bij een dwarse, maatschappijkritische boodschap hoorde ook een non-conformistische filmtaal. Een veelgebruikt stijlkenmerk (ook in de Fugitive-affiches) was de collage. Verschillende filmformaten, kleur en zwart-wit, documentaire en fictie, animatie en archiefbeelden, humor en ernst, Nederlands, Frans en Engels: men laste alles aaneen tot een pamflettair spel van beeld en geluid. Hiermee sloot het collectief niet alleen aan bij internationale tendensen, De Hert en kompanen kregen er ook internationale erkenning voor. Zo won de animatiefilm A Funny Thing Happened on my Way to Golgotha (1968) van Jos en Robbe De Hert op het gerenommeerde kortfilmfestival van Oberhausen de Grote Prijs. Dat had tot gevolg dat de broers het jaar daarop de openingsfilm voor het festival mochten leveren, The Great Temptation of a Pink Elephant (1969). Ook volgende films kregen dikwijls buitenlandse waardering.

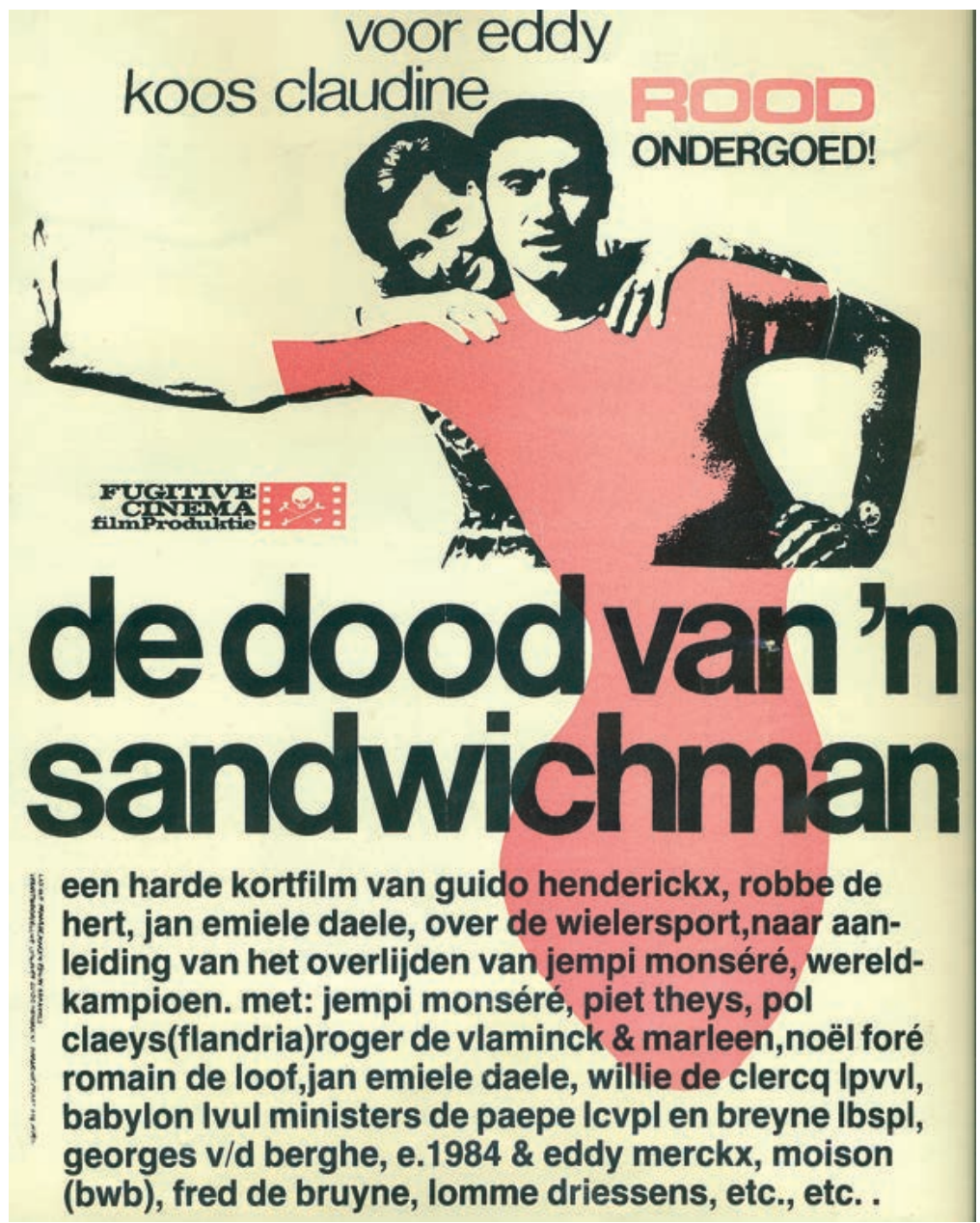


Een van de meest spraakmakende films van het collectief was de sociale reportage S.O.S. Fonske (1968), dat focust op een koppel wiens inboedel in beslag genomen wordt. Aangezien hun verzekeringsmaatschappij failliet is, moeten ze de schade van een auto-ongeval zelf betalen. Volledig in de collectieve geest realiseerden De Hert, Henderickx en Le Bon de film in nauwe samenwerking. Voor de interviews kregen ze de hulp van Buyens. De Hert en Henderickx werkten opnieuw samen voor De dood van een sandwichman (1971), over hoe politieke profileringsdrang en commerciële belangen de begrafenis van het jonge wielertalent Jean-Pierre Monseré kapen. Fugitive Cinema noemde S.O.S. Fonske en De dood van een sandwichman 'off-television productions' omdat de publieke omroep (toen nog de monopolistische BRT) elke medewerking had geweigerd, terwijl Fugitive de onderwerpen en de aanpak net uiterst geschikt vond voor de televisie. Het waren met andere woorden films voor de televisie die de televisie niet wenste.

Heel wat Fugitive-producties golden als filmische vertalingen van de mei '68-contestatie. Het beste voorbeeld daarvan is De Herts eerste langspeler Camera sutra of de bleekgezichten (1973), een militante film die in de karakteristieke collagestijl scherpe kritiek uit op de burgerlijke schijnheiligheid van België. De film mixt eerst fictiebeelden over de groep contesterende jongeren met reportagebeelden, waarbij fictie en non-fictie soms letterlijk in elkaar overlopen. De Hert argumenteert hier dat bierfeesten, sport, IJzerbedevaarten en nationale defilés het volk zoet houden om de aandacht af leiden van de echte problemen in België en de wereld, zoals de beknotting door kapitalisme, kerk en staat, de sociale onrechtvaardigheid en de postkoloniale uitbuiting.

Het tweede deel van de film is een semi-autobiografisch fictieverhaal over de vergeefs revolterende groep jongeren. De Hert speelt zichzelf, net als zijn toenmalige partner, de links en feministisch geëngageerde Ida Dequeecker, die een grote rol speelde in De Herts ideologische vorming. In dit tweede deel toont zich de zelftwijfel van de revolutionairen. De Herts personage aan het begin van de film: 'Ik heb gewetensproblemen. Het enigste wat ik belangrijk vind is gelijk hebben. Dus niet gelijk krijgen, maar gelijk hebben. En ik twijfel of wij gelijk hebben.' Als de personages een vraag wordt gesteld, hebben ze nauwelijks antwoorden. Ze leveren wel strijd met de gendarmerie, maar er is geen doordachte contestatie, ze handelen eerder vanuit een gevoel, vanuit een onmacht die ze niet kunnen verwoorden. Net zoals de huilende kleuters die tijdens de begintitels achtergelaten worden op hun eerste dag naar school, een van de instituten die het maatschappelijk bestel in stand houden. 

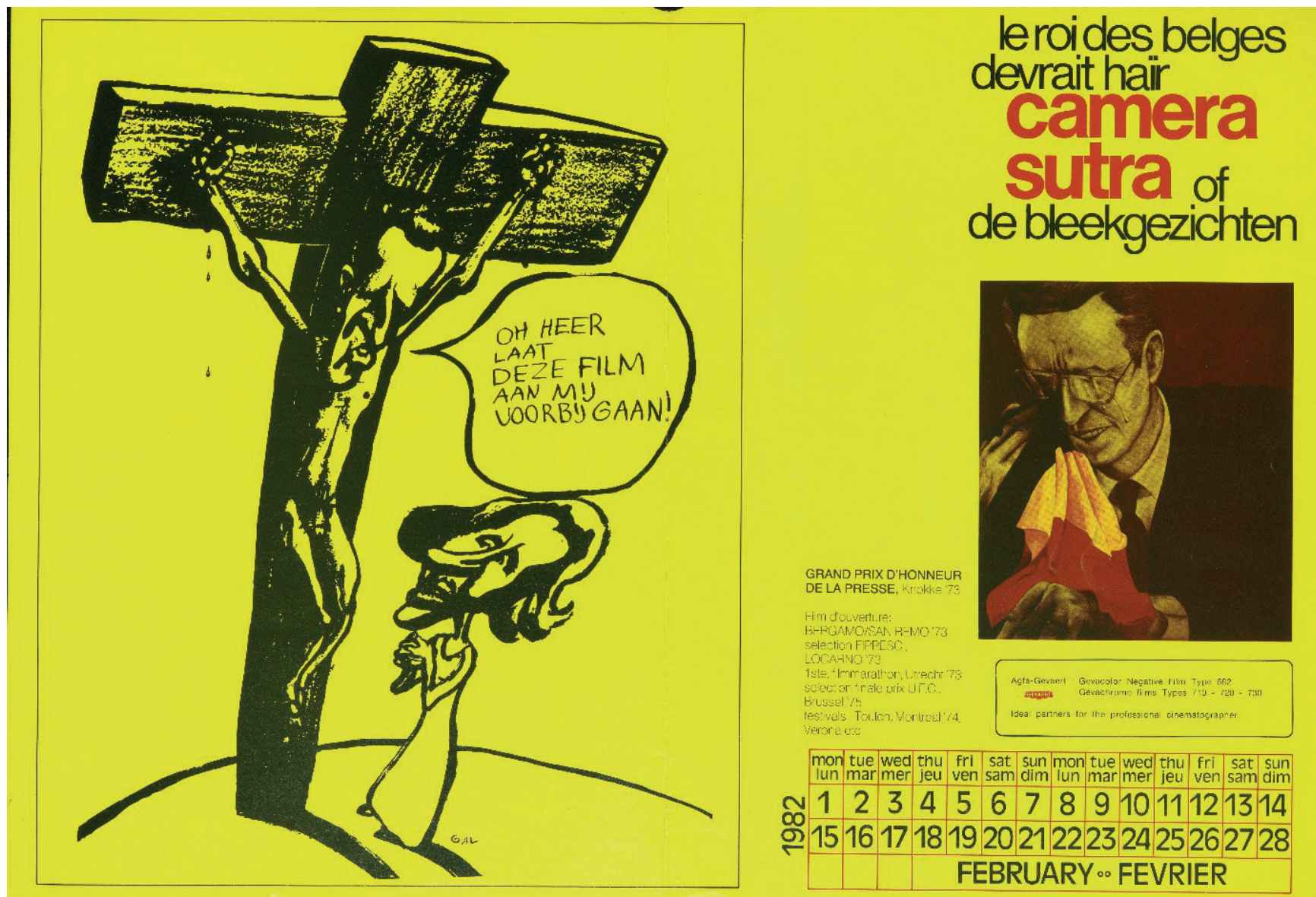

Afbeelding 5: Affiche voor Camera sutra of de bleekgezichten (1973), in de voor Fugitive Cinema karakteristieke maatschappijkritische en humoristische collagestijl. Bron: Collectie Ronnie Pede/Comeet (Erfgoedcel Meetjesland).

De missie van Fugitive Cinema om de mensen via maatschappijkritische films een geweten te schoppen, kende verwantschap met het engagement van de schrijver Louis Paul Boon, met wie De Hert bevriend was. Boon speelde in 1966 een rolletje als pastoor in De Herts kortfilm Insane. In De bom (1969) neemt hij de hoofdrol voor zijn rekening, met aan zijn zijde de Amerikaanse actrice Betsy Blair (de echtgenote van Karel Reisz). Ook Fons Rademakers en Maurice De Wilde hebben een rolletje in de film. Geïnspireerd door een incident uit 1966 waarbij vier Amerikaanse waterstofbommen waren zoekgeraakt in Spanje, handelt de film over een garagist die een atoombom vindt. Hij dreigt ermee de bom tot ontploffing te brengen, tenzij de Belgische regering de defensiekredieten intrekt. Doorheen het fictieve verhaal monteert De Hert straatinterviews en 
archiefbeelden van parlementszittingen. De film is een protest tegen de bewapeningswedloop, maar beklemtoont tevens de machteloosheid van 'gewone' mensen om zich daartegen te verzetten. In 1977 werd de film opnieuw uitgebracht als deel van de anthologiefilm Gejaagd door de winst: Het $A B C$ van de moderne samenleving, samen met twee kortfilms van Guido Henderickx: Gejaagd door de winst, over een ongeluk en doofpotaffaire in de chemische industrie, en Het laatste oordeel, over een bacteriologische ramp.

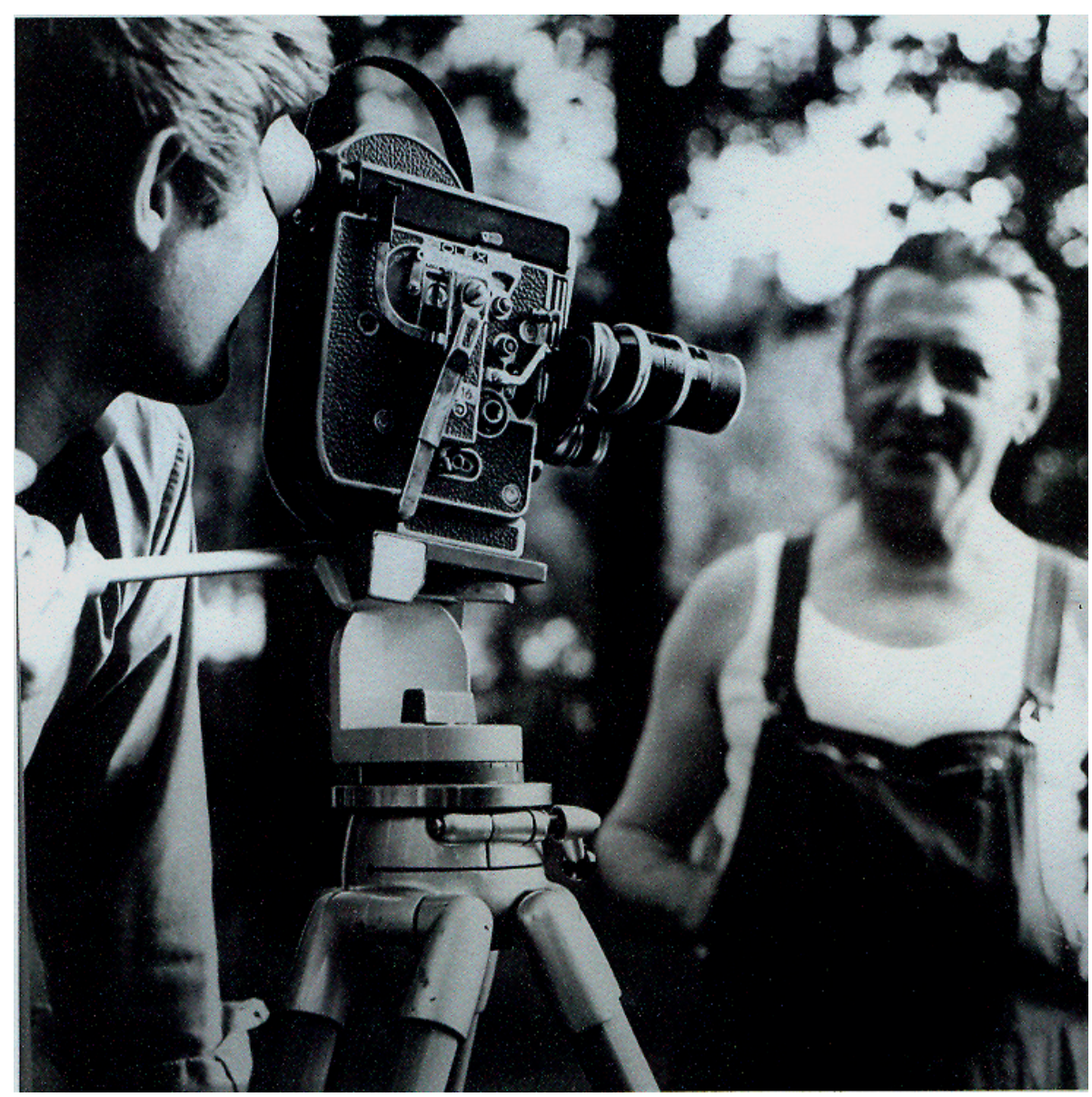

Afbeelding 6: Robbe De Hert filmt Louis Paul Boon op de set van De bom (1969). Bron: Fugitive Cinema Archief.

Ten tijde van de opnames van De bom was Boon bezig aan zijn historische roman Pieter Daens (1971), over de sociale strijd in de fabrieksstad Aalst aan het einde van de negentiende eeuw. De Hert was toen reeds geïntrigeerd door dit onderwerp, en zou zich na Boons overlijden in 1979 vol overgave op een verfilming van het boek storten. ${ }^{7}$ Het financiële en productionele plaatje raakte echter niet 
rond, vooral door het weifelen van de filmcommissie. Na een lijdensweg van tien jaar was De Hert het vechten tegen de bierkaai moe. Producent Dirk Impens en regisseur Stijn Coninx namen het project over, wat in het Oscargenomineerde Daens (1992) uitmondde.

Het werk van De Hert rond een Daensverfilming kende zo toch resultaat. Heel wat andere (vaak vergevorderde) projecten van De Hert zouden nooit afgewerkt raken: een film over het psychiatrisch centrum van Geel tijdens de Tweede Wereldoorlog, een Suske en Wiske-verfilming (Het Spaanse spook), een western over de laatste dagen van Christus... De lijst is bijzonder lang en divers.

\section{Publieksfilms}

Boon had nog een sleutelrol gespeeld in de totstandkoming van het scenario van De Witte van Sichem (1980), waar ook de auteurs Gaston Durnez en Fernand Auwera aan meeschreven. Met 540.000 bioscoopbezoekers was het De Herts eerste en meteen ook grootste publiekssucces. Tot op vandaag lokt iedere televisie-uitzending in België honderdduizenden kijklustigen: de avond voor De Herts overlijden zond VRT-zender één de film nog uit voor 480.601 kijkers.

In hetzelfde jaar als De Witte van Sichem realiseren ook twee andere Fugitive-leden meer mainstream gerichte speelfilms dan men van het collectief gewoon was, al kenden beide films wel nog steeds een sterke sociale inslag. Patrick Le Bon verhaalt in Hellegat over arbeidersprotest, Guido Henderickx herwerkt het thema uit Gejaagd door de winst tot de lange speelfilm De proefkonijnen (waaraan De Hert als second unit regisseur meewerkte). Het verschijnen van deze films, samen met Peter Simons' Het einde van de reis, vormde voor twee critici van Andere Sinema de aanleiding om over 1980 te spreken als het 'wonderlijke jaar van de Vlaamse film'. ${ }^{8}$

De populariteit van De Witte van Sichem zorgde ervoor dat de film in de voetsporen trad van een eerdere adaptatie van Ernest Claes' streekroman uit 1920: de grootste Vlaamse succesfilm ooit, De Witte uit 1934, gerealiseerd door Jan Vanderheyden en Edith Kiel. Maar De Hert gaf, op aanzet van Boon, zijn verfilming een volledig eigen draai: ditmaal geen kolderiek kwajongensverhaal gekoppeld aan een lofzang op het Vlaamse land, maar een sociaalkritische film over een jongen die tracht te ontsnappen aan zijn beklemmende omgeving. Filmische inspiratie haalde De Hert veeleer bij Kes (1969) van Ken Loach dan bij de eerste De Witte. 
TMG $23(1 / 2) 2020$

Gertjan Willems

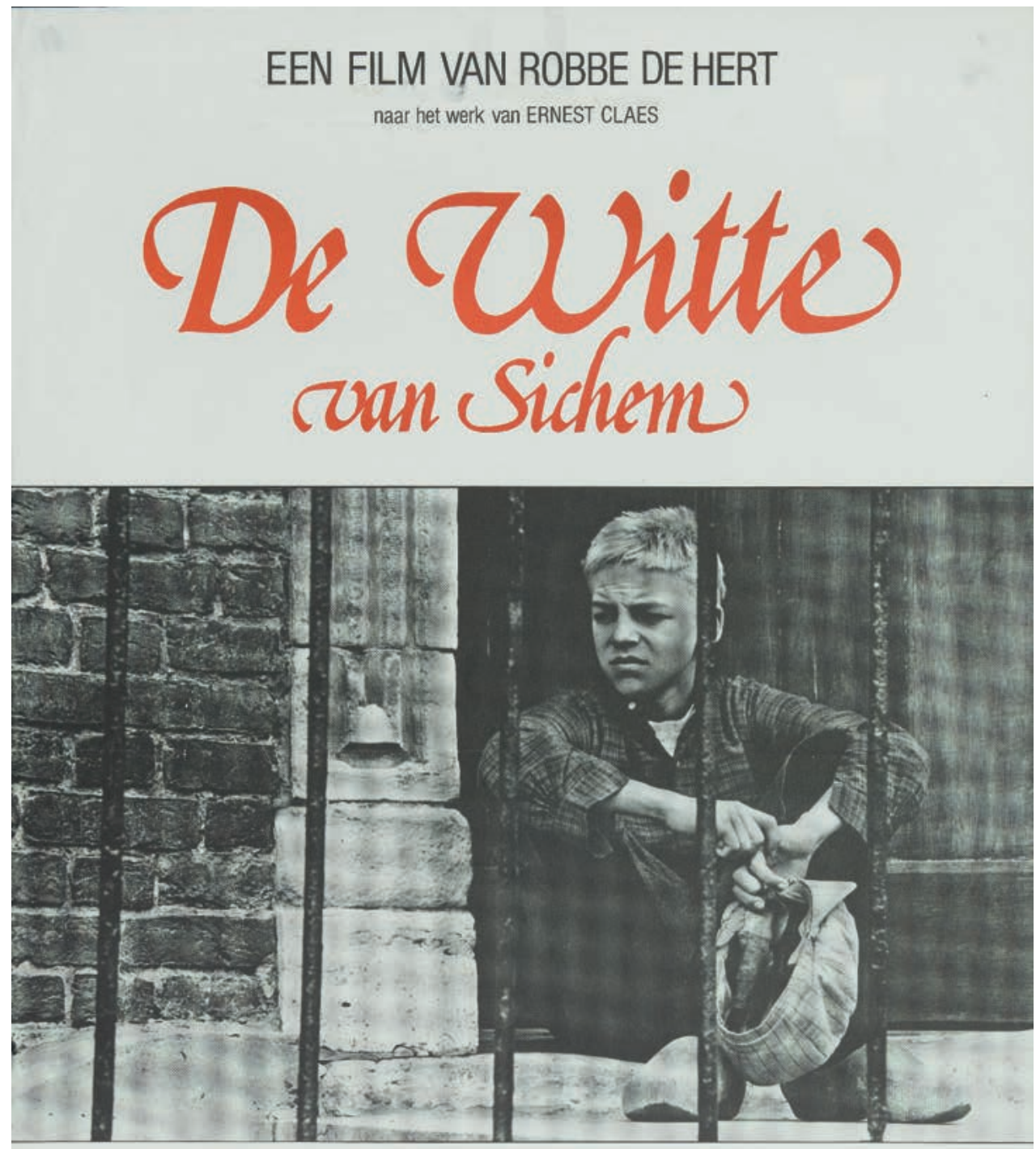

met Paul S'JONGERS, Paul-Emile VAN ROYEN, Willy VANDERMEULEN, Blanca HEIRMAN, Jos VERBIST, Magda DE WINTER, Eric CLERCKX als de Witte, Luc PHILIPS, Martha DEWACHTER, Bert STRUYS als Wannes Raps, Bob STORM, Bob VAN DER VEKEN, Jaak VAN ASSCHE, Herman VERBEEK, Chris LOMME als Rosette

Raph TROCH, Chris CAUWENBERGS, Vic RIBBENS, LOde VAN BEEK, Gil LEFEVER en introducerend Joris SUSTRONCK als de missiepater Guest-stars : Gaston BERGMANS \& Leo MARTIN, Raymond VAN HET GROENEWOUD, Wannes VAN DE VEL.DE e.v.a. Scenario en dialogen : Fernand AUWERA, Robbe DE HERT en Gaston DURNEZ m.mv, Louis-Paul BOON en Hugo CLAUS Fotografie: Walther VANDEN ENDE en Theo VAN DE SANDE Muziek: Jïrgen KNIEPER Lied : Walter HEYNEN en Wannes VAN DE VELDE

NEWSTAR FLLMS \& VISE FLMPPODUKTIE

Afbeelding 7: Affiche voor De Witte van Sichem (1980), De Herts eerste en meteen ook grootste publiekssucces. Bron: Collectie Ronnie Pede/Comeet (Erfgoedcel Meetjesland). 
In zijn kritiek op instituten als de kerk, de school, het gezin en de burgerij leunt De Witte van Sichem eigenlijk vrij dicht aan bij vroeger werk zoals Camera sutra. Maar vormelijk betekent de film een echte breuk in De Herts oeuvre. Narratie, beeldvoering en montage zijn grotendeels geënt op mainstream filmconventies. Iets waar De Hert zich opmerkelijk vakbekwaam in toonde, ook in volgende films. In 1989 regisseert hij de internationale coproductie Trouble in Paradise, een politieke thriller over de illegale wapenhandel en de eurocratie. In hetzelfde jaar mag Blueberry Hill de Nederlandse filmdagen openen. In dit autobiografisch getinte Love story from the fifties, zoals de ondertitel luidt, vertolkt Michaël Pas De Herts jonge alter ego, wat hij opnieuw doet in het vervolg Brylcream Boulevard (1995). Ook in Gaston's War (1997), over een Gentse verzetsstrijder tijdens de Tweede Wereldoorlog, en de Willem Elsschotverfilming Lijmen/Het been (2000), waarvoor Willeke Van Ammelrooy het Gouden Kalf voor Beste Actrice ontving, brengt De Hert vlot vertelde verhalen voor een breed publiek.

In de vroegere, meer experimentele Fugitive-stijl verschenen in 1981 nog de politieke documentaire Le filet américain (waarin de sociaal-economische analyse van de trotskistische econoom Ernest Mandel centraal staat) en in 1982 het minder bekende maar bijzonder interessante Maria Danneels of het leven dat we droomden. In deze televisiefilm zetten De Hert en scenarist Fernand Auwera de opdracht van de BRT om een - volgens hen doodvervelende - roman van Maurice Roelants te verfilmen volledig naar hun hand ('à la Godard', dixit De Hert). ${ }^{9}$ Niet alleen voegden ze een politieke dimensie toe, ook lasten ze een reflexieve raamvertelling in over de worsteling van een scenarist die Roelants' boek tegen zijn zin dient te herwerken tot een filmscript. Nadien zou De Hert dit soort alternatieve films niet meer maken, al zou zijn cinefiel en sociaal engagement wel in bijna al zijn werk zichtbaar blijven.

Zijn overgang naar 'publieksfilms' kwam voor velen als een grote verrassing. Zeker toen De Hert in 1984 Zware jongens regisseerde, de eerste Vlaamse populaire filmkomedie sinds Edith Kiel in 1961 haar laatste Antwerpse volksfilm had gedraaid. Het komische duo Gaston Berghmans en Leo Martin ('Gaston en Leo') staat centraal in deze met sketches, misverstanden en verbale humor gelardeerde film. Met 365.000 bioscoopbezoekers bleek een film met bekende televisiekomieken een succesformule die al snel navolging kende. ${ }^{10}$ Zo geldt Zware jongens niet alleen als wegbereider voor twee volgende Gaston en Leo-films (Paniekzaaiers in 1986 en Gaston en Leo in Hong Kong in 1988), maar ook voor de populaire Urbanus-films Hector (1987) en Koko Flanel (1990), Max (1994) met Jacques Vermeire, de Chris Van den Durpel-films Oesje! (1997) en Firmin (2007), en voor de vier F.C. De Kampioenen-films die tussen 2013 en 2019 de Vlaamse zalen deden vollopen. 
TMG 23 (1/2) 2020

Gertjan Willems

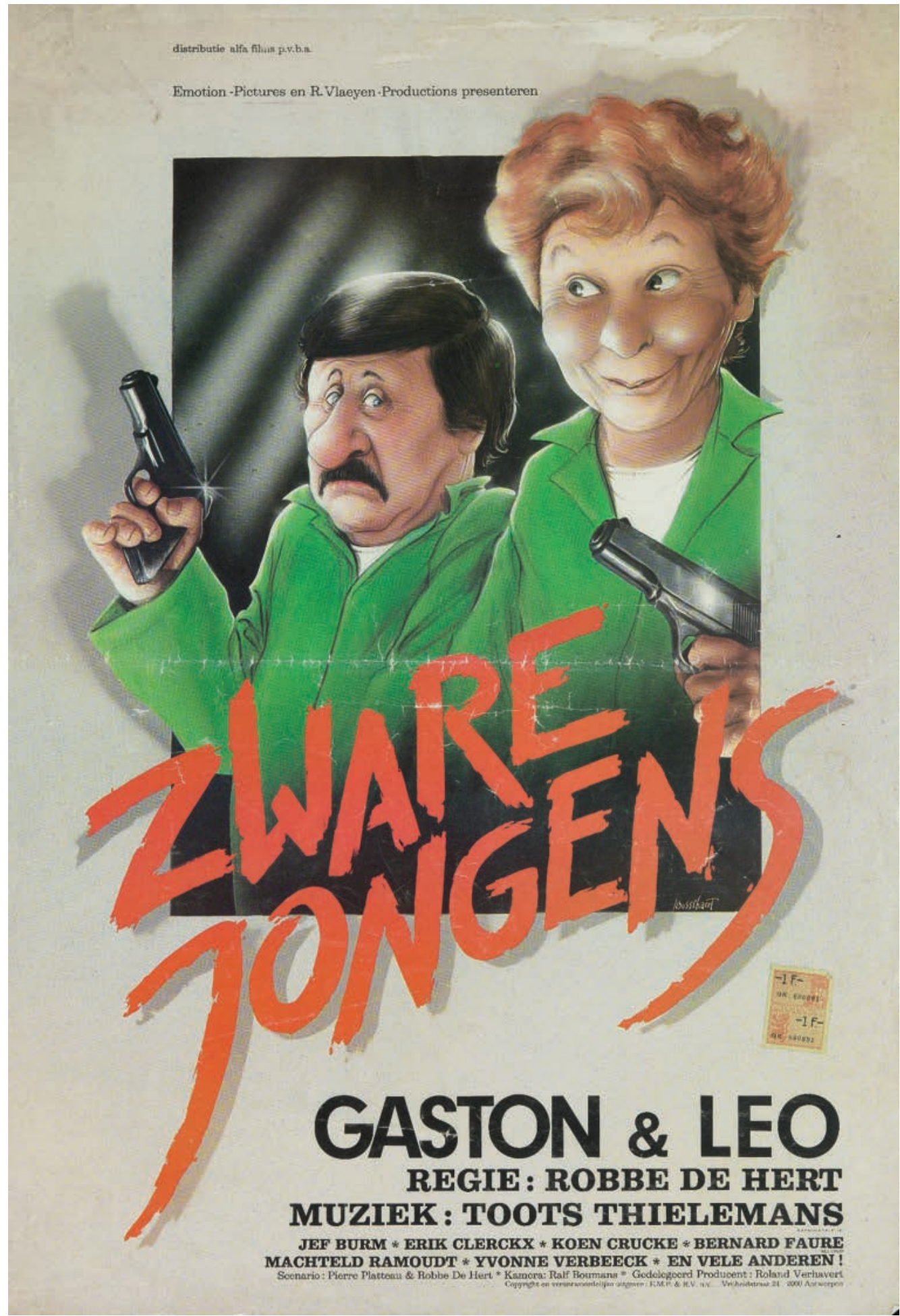

Afbeelding 8: Affiche voor Zware jongens (1984), die een reeks populaire films met televisiekomieken initieerde. Bron: Collectie Ronnie Pede/Comeet (Erfgoedcel Meetjesland). 
Zware jongens had ook een belangrijke productioneel-economische impact op de Vlaamse filmsector: voor het eerst werd in Vlaanderen op dergelijke schaal gebruik gemaakt van private investeringen en sponsoring. In tijden van overheidsbesparingen op cultuur bood het sponsorexperiment een financieel interessante piste. Voor De Hert paste dit ook in zijn idee om aan te tonen dat winstgevende films maken in Vlaanderen wel degelijk mogelijk was. De opbrengsten wou hij dan gebruiken om andere, commercieel moeilijkere films te financieren. ${ }^{11}$ Dat neemt niet weg dat een populaire komedie met een overdaad aan prominente sponsoring (Patrick Duynslaegher titelde zijn Knack-recensie 'Danone, Gastone \& Leone') ${ }^{12}$ haaks leek te staan op De Herts vroegere kritiek op de commercialisering van de samenleving. Maar voor De Hert was het belangrijkste goed films maken. En waar hij in de jaren 1960 en 1970 verkondigde dat hij maar wat graag genrefilms wilde maken, maar dat de toestand van de wereld hem tot alternatieve films dwong, zou hij vanaf de jaren 1980 zijn maatschappijkritiek trachten te verwerken in mainstreamfilms.

\section{Chroniqueur van de filmgeschiedenis}

Vanaf de jaren 1980 begon De Hert zich ook te richten op documentaires over film. Dat hoeft niet te verwonderen. Personages die een bioscoop bezoeken, het inlassen van klassieke filmfragmenten, of een metareflectie zoals in Maria Danneels: De Herts films tonen steeds zijn passie voor de cinema. Vaak is het een liefdesverklaring, maar even dikwijls getuigen de films van een kritische politiekeconomische benadering van het medium.

Dezelfde dubbele houding vinden we terug in De Herts filmdocumentaires, waarvan $D e$ droomproducenten (1984) de eerste was. Oorspronkelijk wilde men in 1976 tien jaar Fugitive Cinema 'vieren' met een film over de vele projecten die in de loop der jaren sneuvelden op het slagveld van de Vlaamse filmproductie. ${ }^{13}$ Maar de film werd zelf het slachtoffer van wat hij trachtte aan te klagen en werd pas opgeleverd in 1984. Producent/regisseur Willem Thijssen (De Herts regieassistent bij De Witte van Sichem) had in Nederland het extra geld voor de voltooiing van de film gevonden. Het project groeide uit tot een film waarin De Hert, Thijssen en monteur Chris Verbiest allerlei misstanden in de Belgische en Nederlandse filmindustrie aan de kaak stellen, de verhouding tussen film en televisie voorop. Via een montage van interviews, filmfragmenten en door Nicole Van Goethem aangeleverde animatiestukken vormt de film in de eerste plaats een kritiek, maar toont hij evengoed De Herts interesse voor de filmgeschiedenis van de Lage Landen. 


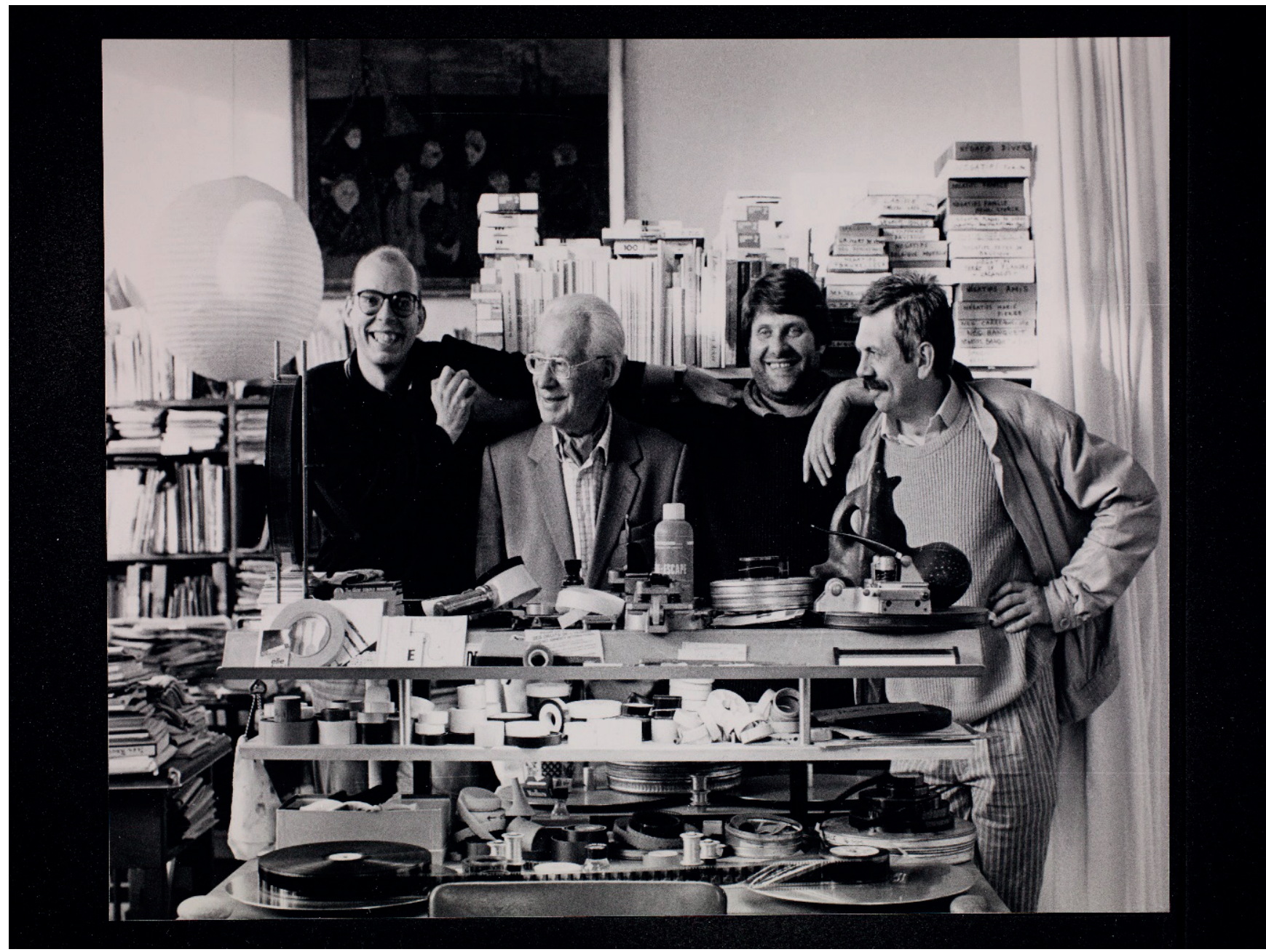

Afbeelding 9: V.l.n.r.: Rik Stallaerts, Henri Storck, Robbe De Hert en Maurice Noben tijdens de realisatie van Henri Storck, ooggetuige (1987). Bron: Rik Stallaerts.

Die interesse diepte hij samen met Rik Stallaerts uit in Henri Storck, ooggetuige (1987). Storck, de internationaal gevierde filmpionier, werkte zelf mee aan deze film. Hoewel hij er geen interview voor wilde geven, beschouwde hij de film als zijn testament. Op sommige momenten sluit de documentaire volledig aan bij de Fugitive-collagestijl, bijvoorbeeld in het monteren van John Lennons ‘Working class hero' boven beelden uit Misère au Borinage (1934), Storck en Joris Ivens' mijlpaal uit de sociale filmgeschiedenis (De Hert had deze specifieke muziekbeeldcombinatie ook al gebruikt in Camera sutra). Op het vlak van de speelfilm verlaat De Hert vanaf de jaren 1980 de vroegere Fugitive-stijl. Maar zijn filmdocumentaires, met hun montage 
van filmfragmenten, reportagebeelden, en interviews, in combinatie met een kritische instelling, liggen op veel vlakken in de lijn van de alternatieve Fugitive-producties uit de jaren 1960 en 1970. Met dat verschil dat nu niet langer de maatschappij, maar wel de cinema centraal staat.

Na de focus op één cineast koos De Hert voor een vogelperspectief. In Janssen en Janssens draaien een film (1990) belicht hij samen met co-regisseur Luc Pien de Vlaamse cinema sinds de invoering van de culturele filmsteun in 1964. In Op de fiets naar Hollywood (1993) richt hij zich samen met co-regisseur Willem Thijssen op de Nederlandse cinema sinds de oprichting van de Nederlandse Filmacademie in 1958. Beide documentaires hebben zowel aandacht voor esthetische ontwikkelingen als voor (de vaak gebrekkige) filmindustriële structuren.

Intussen ontdekte De Hert het boek als medium om de filmgeschiedenis te verspreiden. Met Rik Stallaerts verzamelde hij in Binnenkort in deze zaal (1995) een indrukwekkende selectie Belgische filmaffiches. ${ }^{14}$ Naar aanleiding van de tentoonstelling Magie van de cinema in het Antwerpse Fotomuseum in 2004 verscheen een gelijknamig boek, samengesteld door De Hert en Willy Magiels. ${ }^{15}$ Ze verzamelden hierin een amalgaam aan bijdragen en getuigenissen over uiteenlopende aspecten van het filmgebeuren in België.

Zijn memoires Het drinkend hert bij zonsondergang (1983) en Het drinkend hert in het nauw (2003) geven inzicht in De Herts eigenzinnig leven, werk en denken. ${ }^{16}$ De laatste jaren werkte hij aan een derde Drinkend hert, dat nu onafgewerkt blijft. De Herts memoires getuigen van zijn obsessie voor alles wat van ver of dicht met film te maken heeft en van zijn leven op de barricaden. Maar de toon in de twee boeken is erg verschillend. Waar De Herts tirade in 1983 nog een rebels plezier uitstraalde, klinkt zijn klaagzang over de moeilijke filmomstandigheden in Vlaanderen twintig jaar later een stuk bitterder.

Die evolutie is kenmerkend voor De Herts laatste carrièrefase, waarin hij geen speelfilmprojecten meer van de grond kreeg en hij de media vooral haalde met zijn gezondheids- en financiële problemen. Al kreeg hij ook erkenning: het Koninklijk Belgisch Filmarchief CINEMATEK restaureerde een selectie van zijn vroege films, de VRT realiseerde in 2014 een televisiedocumentaire over zijn carrière, hij kreeg van het Filmfestival Oostende een ster op de zeedijk, en dankzij een crowdfundingsactie, tax shelter geld, en steun van de Stad Antwerpen en de minister van Cultuur, kon zijn laatste documentaire, Hollywood aan de Schelde (2018), afgewerkt worden. 


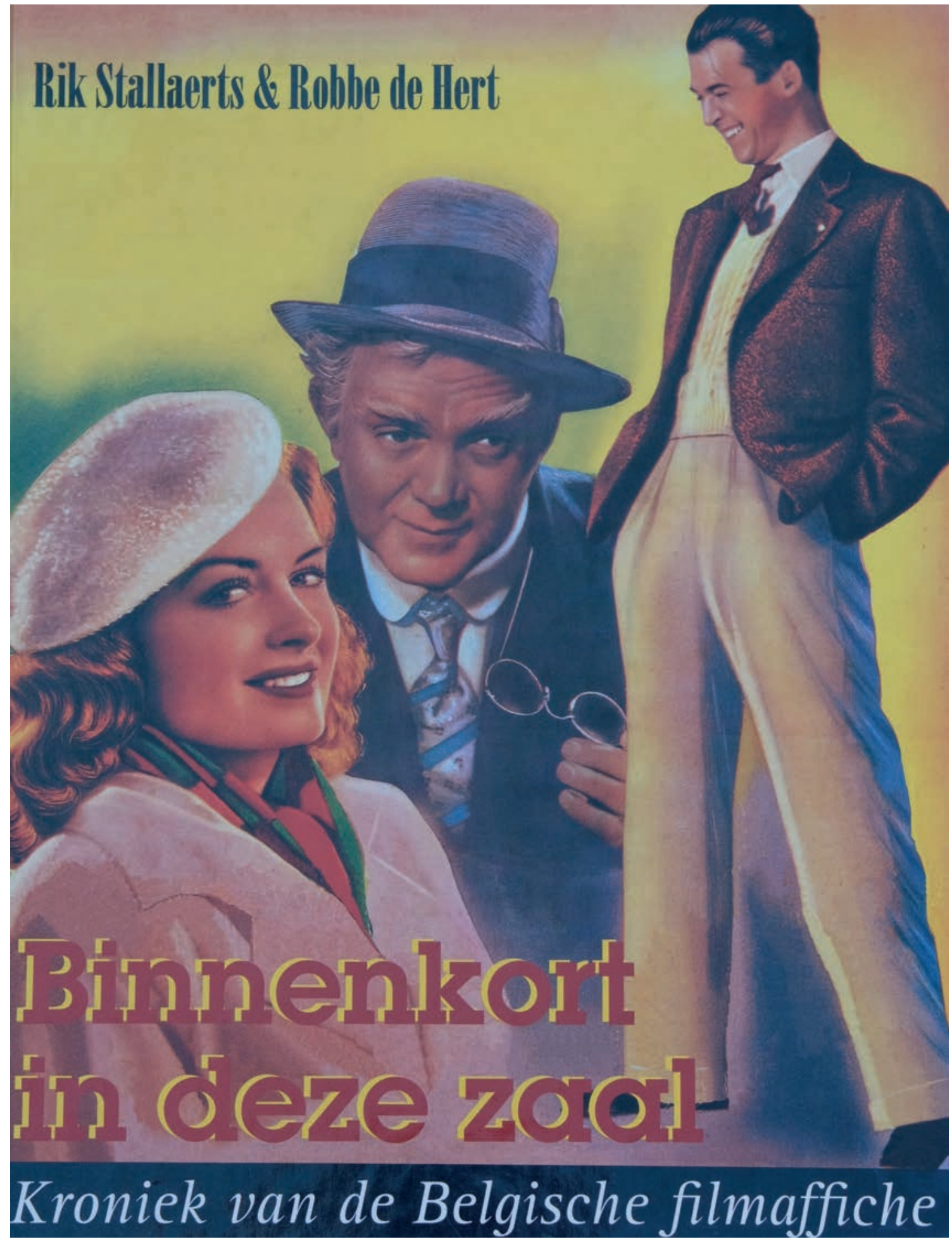

Afbeelding 10: Cover van het boek Binnenkort in deze zaal. Kroniek van de Belgische filmaffiche (1995). Bron: Rik Stallaerts. 
Uit zijn memoires blijkt ook De Herts haat-liefdeverhouding met Antwerpen. De verwevenheid tussen cineast en stad leidde onder andere tot de montagefilm Antwerpen in de cinema (1994) en de compilatiefilm Elixir d'Anvers (1996), geregisseerd door vier Vlaamse en twee Nederlandse jonge regisseurs onder supervisie van De Hert en opnieuw in coproductie met Willem Thijssen. In 2001 startte De Hert onder de titel Hollywood aan de Schelde een televisiereeks over het Antwerpse filmgebeuren (met bijvoorbeeld episodes over de volksfilms van Edith Kiel en over het Rex-imperium van Georges Heylen), wat zou uitgroeien tot een algemene geschiedenis van de film in Vlaanderen en België. Na diverse moeilijkheden mondde dit in 2018 uit in de lange documentaire met dezelfde titel, De Herts laatste wapenfeit. Zoals wel vaker bij De Herts werk weegt de anekdotiek sterker door dan de structurele analyse. Maar de waarde van Hollywood aan de Schelde ligt ook in de jarenlange research. De Hert verzamelde voor zijn passieproject dozen vol documentatie en zo'n 220 uur uniek interviewmateriaal met diverse kroongetuigen.

\section{Fugitive Cinema Archief}

De meeste van die dozen liggen in het Filmhuis Klappei in Antwerpen, waar De Hert sinds 2006 bureau hield. Op de tweede verdieping bevinden zich zes kamers volgestouwd met persknipsels, boeken, tijdschriften, films, scenario's, correspondentie, awards, affiches en ander materiaal. De Hert gooide amper iets weg, waardoor zijn archiefkamers een goede weerspiegeling vormen van zijn rijkgevuld, geschakeerd en chaotisch leven. De Herts positie als centraal figuur in de Belgische film- en culturele wereld sinds de jaren 1960 maakt dat de historische waarde van dit archief buiten kijf staat.

In april 2020 vatte ik het plan op om samen met Steven Jacobs aan de Universiteit Antwerpen een onderzoeksseminarie te organiseren rond Fugitive Cinema. De Hert was meteen enthousiast en stelde zijn archief ter beschikking. Maar het werd al snel duidelijk dat het eerste werk erin bestond orde te scheppen in de chaos van het archief, en er een duurzaam onderkomen voor te zoeken, weg van de schimmels die het materiaal aan het aantasten waren. Dankzij tussenkomst van De Herts compagnon Jim Van Leemput kon de Universiteit Antwerpen het archief verwerven. Het wordt nu overgedragen aan het Felixarchief, het Antwerpse Stadsarchief. Met de hulp van Van Leemput schonk De Hert tien dagen voor zijn overlijden ook nog het archiefmateriaal dat bij hem thuis lag aan de universiteit en het Felixarchief. Dat zal worden samengevoegd met het materiaal in Filmhuis Klappei. 


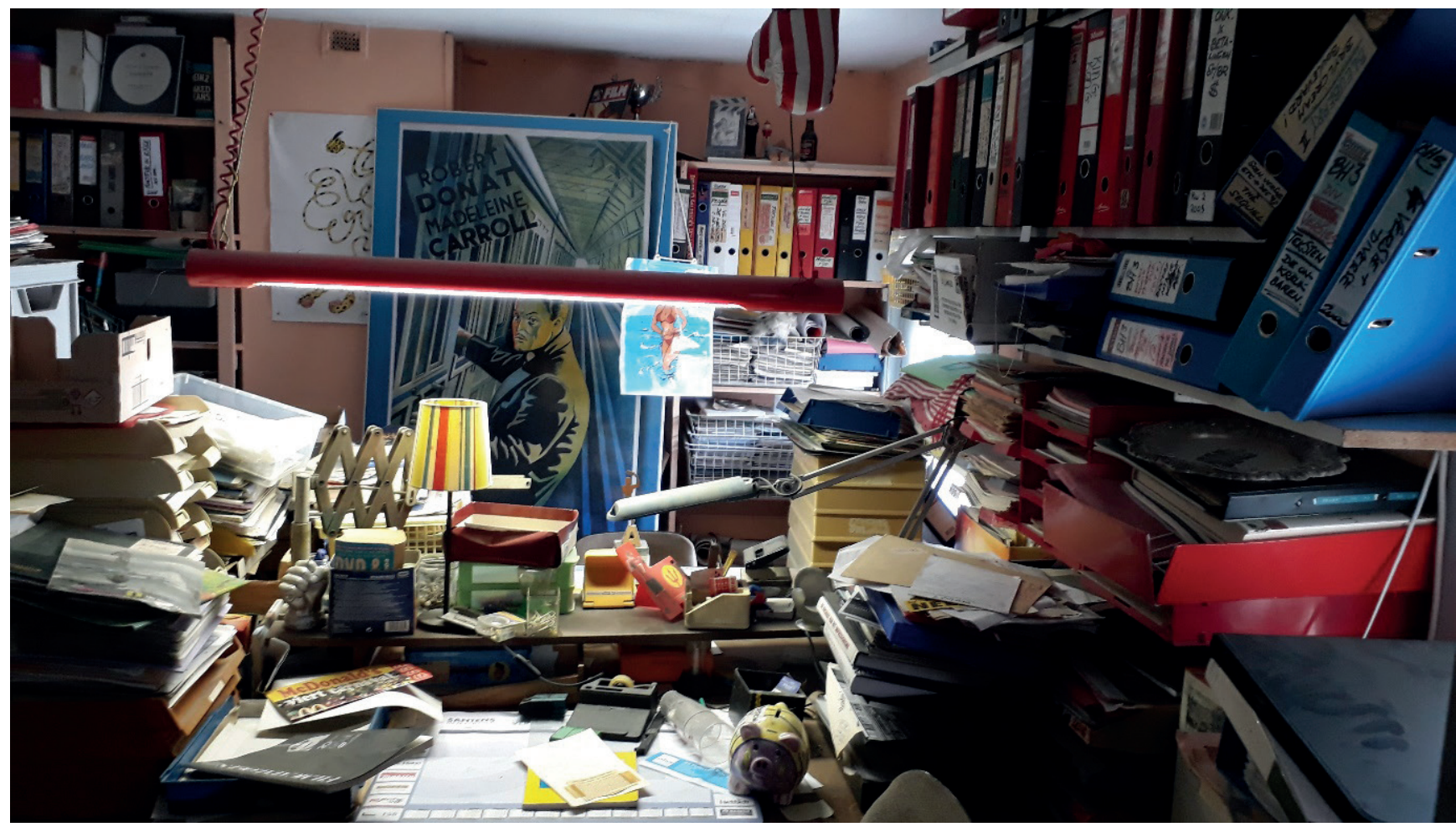

Afbeelding 11: Robbe De Herts bureau in Filmhuis Klappei. Bron: Fugitive Cinema Archief.

De Hert stond erop het archief niet naar hem persoonlijk te noemen, maar dat het 'Fugitive Cinema Archief' zou heten, net omdat de relevantie van het archief breder gaat dan enkel zijn eigen films en projecten. In juli startte de ordening en een eerste beschrijving van het archief. Vervolgens wordt alles schoongemaakt en geïnventariseerd, waarna het materiaal publiek toegankelijk zal zijn in het Felixarchief. De filmkopieën (in diverse formaten) heeft het Felixarchief intussen al ondergebracht bij CINEMATEK. Meemoo, het Vlaams instituut voor het archief, werkt mee aan de digitalisering en duurzame bewaring van het audiovisueel materiaal. Dankzij de ontsluiting van een belangrijke brok filmgeschiedenis van de Lage Landen kan De Herts werk als chroniqueur en promotor van die filmgeschiedenis verdergezet worden. ${ }^{17}$ 


\section{Notes}

1 Kathleen Lotze en Philippe Meers, “Citizen Heylen. Opkomst en bloei van het Rex-concern binnen de Antwerpse bioscoopsector (1950-1975)," Tijdschrift voor Mediageschiedenis 13, nr. 2 (2010): 80-107.

2 Wim De Poorter, “Het idealisme van Fugitive Cinema” Ons Erfdeel 27, nr. 2 (1984): 252-258.

3 Maria Rosseels in de documentaire Belfilm: Robbe De Hert (2014, VRT Televisie).

4 Joz. Van Liempt, “25 jaar recht door zee,” in 25 years Fugitive Cinema (Antwerpen: Fugitive Cinema, 1991), 48.

5 Voor de relatie tussen het filmbeleid en Fugitive Cinema, zie Gertjan Willems, Subsidie, camera, actie! Filmbeleid in Vlaanderen 1964-2002 (Gent: Academia Press, 2017), 180-182.

6 Ernest Mathijs, “Bad Reputations: The Reception of Trash Cinema,” Screen 46, nr. 4 (2005): 454.

7 Gertjan Willems, “Daens: de making-of. Over de film Daens (1992) en de Daensmythe,” WT Tijdschrift over de Geschiedenis van de Vlaamse Beweging 78, nr. 3 (2019): 204-208.

8 Mark Holthof en Marc Ruyters, 1980, het wonderlijke jaar van de Vlaamse film (Berchem: EPO, 1980).

9 Erik Martens, “Maria Danneels: de verfilming waarvan niemand droomde,” Vlaanderen 54, nr. 304 (2005): 22 .

10 Gertjan Willems, "Van cultureel verantwoorde naar plezante films. De heropleving van populaire komedies in de jaren tachtig en de rol van het Vlaamse filmbeleid," Volkskunde: Tijdschrift over de Cultuur van het Dagelijks Leven 117, nr. 2 (2016): 143-161.

11 Gilbert Verschooten, Robbe De Hert, (Brussel: Fantasy Film, 1991), 17-18.

12 Patrick Duynslaegher, “Danone, Gastone \& Leone: Het laatste nieuws van Robbe De Hert: Zware jongens, o solo mio!," Knack, 11 april 1984, 172.

13 Wim De Poorter, “De droomproducenten,” Ons Erfdeel 28, nr. 1 (1985): 127.

14 Rik Stallaerts en Robbe De Hert, Binnenkort in deze zaal: Kroniek van de Belgische filmaffiche (Gent: Ludion, 1995).

15 Willy Magiels en Robbe De Hert, red., Magie van de cinema (Antwerpen: Facet, 2004).

16 Robbe De Hert, Het drinkend hert bij zonsondergang: Het jungle boek van de Vlaamse film (Leuven: Kritak, 1983); Robbe De Hert, Het drinkend hert in het nauw (Leuven: Van Halewijck, 2003).

17 Dit artikel is een herwerkte en uitgebreide versie van een tekst die eerder verscheen op Sabzian (https:// www.sabzian.be/text/leven-voor-de-film-robbe-de-hert-1942-2020). Dank aan Gerard-Jan Claes en Willem 
Thijssen voor de feedback op verschillende versies. Dank ook aan Ronnie Pede, Rik Stallaerts en Kris Verdonck voor het aanleveren van beeldmateriaal.

\section{Biografie}

Gertjan Willems is docent aan de Universiteit Antwerpen, waar hij verbonden is aan de departementen Letterkunde en Communicatiewetenschappen en aan de onderzoeksgroepen Research Centre for Visual Poetics en Visual and Digital Cultures Research Center. Daarnaast is hij als postdoctoraal onderzoeker van het Fonds Wetenschappelijk Onderzoek - Vlaanderen (FWO) verbonden aan het Centre for Cinema and Media Studies van de Universiteit Gent. Hij is auteur van Subsidie, camera actie! Filmbeleid in Vlaanderen 1964-2002 (2017, Academia Press) en redigeerde samen met Bruno De Wever de bundel De verbeelding van de leeuw. Een geschiedenis van media en natievorming in Vlaanderen (2020, Peristyle). 
TMG 23 (1/2) 2020

Gertjan Willems

\section{TMG Journal for Media History}

Volume 23 No (1/2)/2020

\section{DOI}

https://dx.doi.org/10.18146/tmg.793

\section{PUBLISHER}

Netherlands Institute for Sound and Vision

\section{COPYRIGHT}

Each article is copyrighted (c) by its author(s) and is published under license from the author(s). When a paper is accepted for publication, authors will be requested to agree with the Creative Commons Attribution 4.0 International License. 